\title{
BRPKM
}

Buletin Riset Psikologi dan Kesehatan Mental

http://e-journal.unair.ac.id/index.php/BRPKM

e-ISSN: 2776-1851

ARTIKEL PENELITIAN

\section{Pengaruh Keberfungsian Keluarga terhadap Penyesuaian Akademik pada Mahasiswa Tahun Pertama Selama Proses Pembelajaran Daring}

\author{
Silvia Febriyanti Igirisa \& Nono Hery Yoenanto* \\ Fakultas Psikologi Universitas Airlangga
}

\begin{abstract}
ABSTRAK
Transisi dari sekolah menuju perkuliahan merupakan fase yang menimbulkan berbagai tantangan sehingga menuntut mahasiswa untuk dapat melakukan penyesuaian akademik, terlebih pada situasi pandemi Covid-19. Proses penyesuaian akademik membutuhkan dukungan dari pihak keluarga yang berfungsi secara sehat. Penelitian ini bertujuan untuk menganalisis pengaruh keberfungsian keluarga terhadap penyesuaian akademik pada mahasiswa tahun pertama selama proses pembelajaran dalam jaringan. Penelitian ini menggunakan pendekatan kuantitatif dengan metode survei yang melibatkan 254 partisipan. Instrument penelitian yang digunakan adalah skala Student Adaptation to College Questionnaire dan Family Assessment Device. Hasil dalam penelitian ini menunjukkan bahwa keberfungsian keluarga memiliki pengaruh positif dan signifikan terhadap penyesuaian akademik pada mahasiswa tahun pertama selama proses pembelajaran daring sebesar 29,7\%.
\end{abstract}

Kata Kunci: keberfungsian keluarga, mahasiswa tahun pertama, pembelajaran dalam jaringan

\section{ABSTRACT}

The transition from school to lectures is a phase that poses various challenges that require students to be able to make academic adjustments, especially in the Covid-19 pandemic situation. The academic adjustment process requires the support of a healthy functioning family. This study aims to analyze the effect of family functioning on academic adjustment in first year students during the online learning process. This study uses a quantitative approach with a survey method involving 254 participants. The research instrument used was the Student Adaptation to College Questionnaire scale and the Family Assessment Device. The results in this study indicate that family functioning has a positive and significant effect on academic adjustment in first year students during the online learning process by $29.7 \%$.

Keywords: family functions, academic adjustment, first year students, online learning

Buletin Penelitian Psikologi dan Kesehatan Mental (BRPKM), 2021, Vol. 1(2), 1435-1443

*Alamat korespondensi: Fakultas Psikologi Universitas Airlangga, Kampus B Universitas Airlangga Jalan Airlangga 4-6 Surabaya 60286. Surel: nono.hery@psikologi.unair.ac.id

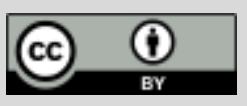

Naskah ini merupakan naskah dengan akses terbuka dibawah ketentuan the Creative Common Attribution License (CC-BY-4.0) (http://creativecommons.org/licenses/by/4.0), sehingga penggunaan, distribusi, reproduksi dalam media apapun atas artikel ini tidak dibatasi, selama sumber aslinya disitir dengan baik. 


\section{PEN D A H U L U A N}

Kini Covid-19 telah menjadi sebuah pandemi yang cukup memberikan dampak besar bagi kehidupan manusia diberbagai belahan dunia. Seluruh sektor kehidupan di dunia menjadi terganggu dengan adanya virus tersebut, tanpa terkecuali dengan sektor pendidikan. Menanggapi hal tersebut, pemerintah Indonesia mengeluarkan kebijakan melalui surat edaran Mendikbud terkait dengan pelaksanaan pembelajaran Nomor 36962/MPK.A/HK/2020 menyatakan bahwa seluruh kegiatan belajar mengajar baik di sekolah maupun kampus perguruan tinggi dianjurkan untuk dilaksanakan dengan sistem pembelajaran dalam jaringan (daring) dalam hal ini sebagai bentuk upaya pencegahan terhadap penyebaran Covid-19 (Hasanah dkk., 2020). Situasi ini menuntut peserta didik untuk dapat beradaptasi dengan berbagai perubahan sistem kehidupan. Hal ini tentu memberikan dampak terhadap keberlangsungan proses pendidikan di Indonesia. Perubahan sistem pembelajaran secara tiba-tiba yang disebabkan oleh situasi pandemi ini membutuhkan penyesuaian diri kepada para peserta didik dalam bidang akademik. Menurut Schneider (1964 dalam Fajriani dkk., 2020) penyesuaian diri merupakan suatu proses yang terjadi saat individu berusaha untuk mengatasi atau menguasai kebutuhan dalam diri, ketegangan, frustasi, dan konflik dengan tujuan untuk mendapatkan keharmonisan serta keselarasan antara tuntutan lingkungan dimana ia tinggal dengan tuntutan di dalam diri sendiri. Dalam situasi pandemi saat ini, peserta didik akan mengalami kendala dalam proses penyesuaian diri mereka melalui berbagai hal baru yang harus dihadapi dalam kehidupan new normal yang mulai dapat diterapkan saat ini.

Perbedaan ini akan sangat dirasakan khususnya bagi siswa sekolah menengah yang akan melanjutkan pendidikan ke perguruan tinggi, dimana peserta didik akan dihadapkan dengan kondisi yang berbeda dengan yang biasanya ia temui disekolah. Awal tahun pertama dalam menjalani masa perkuliahan merupakan fase transisi kritis yang akan dihadapi oleh peserta didik, sebab fase ini sebagai waktu peserta didik dalam menentukan dasar atau prinsip yang akan dilakukan untuk kemudian akan mempengaruhi capaian akademik. Keberhasilan akademik peserta didik akan ditentukan oleh penyesuaian yang dilakukan oleh peserta didik selama proses akademiknya. Berdasarkan hasil penelitian yang dilakukan oleh Porter (1982 Sulfiana, 2015) menunjukkan bahwa mahasiswa yang tidak memiliki penyesuaian akademik baik disebabkan oleh tuntutan akademik yang kemudian berimbas kepada stress sehingga membuat mereka meninggalkan perkuliahan tanpa menyelesaikannya.

Berdasarkan hasil survei awal dilapangan oleh peneliti kepada salah seorang mahasiswi tahun pertama di Fakultas Psikologi Universitas Airlangga yang menyatakan bahwasanya kegiatan belajar daring ini terasa sangat berat karena yang biasanya saat disekolah melakukan proses belajar tatap muka kini harus menggunakan media perantara yang memiliki banyak gangguan dan hal ini membuat sulitnya materi pembelajaran diterima dengan baik, belum lagi ditambah dengan beban tugas yang datang menumpuk, kesulitan dalam beradaptasi pada masa perkuliahan dalam kondisi pandemi ini membuat nilai IPK menjadi tidak sesuai harapan. Berbagai perubahan yang dihadapi peserta didik tahun pertama selama pembelajaran daring menuntut adanya penyesuaian akademik yang dapat mempengaruhi capaian prestasi mereka selama masa studi.

Menurut Baker \& Siryk (1984) academic adjustment merupakan sebuah bentuk kesuksesan mahasiswa dalam melakukan coping terhadap berbagai tuntutan dibidang akademik yang meliputi motivasi, performa, dan lingkungan akademis. Terdapat dua faktor yang mempengaruhi penyesuaian akademik mahasiswa yakni faktor internal dan faktor eksternal, faktor internal merupakan faktor yang berasal dari dalam diri individu yang meliputi kondisi jasmani, psikologis, kebutuhan, kematangan, intelektual, emosional, mental dan motivasi. Sedangkann faktor eksternal merupakan faktor yang berasal dari 
lingkungan meliputi rumah, keluarga, sekolah dan masyarakat. Menurut Schneiders (1964 dalam Khotimatussannah dkk., 2021) dijelaskan bahwa kondisi psikologis ditunjukkan dengan keadaan mental yang sehat, sehingga individu yang memiliki mental sehat mampu melakukan kontrol terhadap dirinya dalam perilakunya secara efektif.

Keluarga merupakan lingkungan sosial terkecil yang menjadi bagian paling pertama dan utama dalam memberikan pendidikan kepada manusia. Pendidikan utama seseorang ditemukan dalam lingkungan keluarga. Keluarga memiliki andil yang sangat besar dalam proses tumbuh kembang anak menuju kedewasaannya. Menurut Hikam (2020) apabila kehidupan keluarga dapat dibina dengan baik, maka kehidupan bermasyarakat akan baik pula. Keluarga menjadi sebuah wadah dan tempat untuk tumbuh dan berkembangnya anak-anak (keluarga) secara keseluruhan, maka dari itu keluarga mempunyai peran yang sangat besar dalam pembentukan jiwa dan kepribadian seorang anak, karena pribadi dan jiwa anak sangat bergantung pada stimulasi orang tua dalam keluarga tersebut (Framanta, 2020).

Lingkungan keluarga memiliki jalinan hubungan yang sangat erat antara anak dan orang tua, dimana hubungan erat tersebut berbeda dengan hubungan yang terjalin diluar keluarga yakni pada masyarakat di lingkungan luas. Dalam memberikan perhatian dan dukungan kepada anak, orang tua dan keluarga harus memiliki pemahaman tentang bagaiamana peran serta fungsi dari keluarga khususnya dalam proses pertumbuhan anak berdasarkan konsep psikologi perkembangan. Pada konsep psikologi perkembangan terdapat teori yang menjadi acuan dalam memberikan pengetahuan kepada orang tua dan keluarga bahwasanya pertumbuhan dan perkembagan anak akan maksimal apabila terdapat dukungan dari orang tua dan keluarga yang juga maksimal. Adanya hal tersebut, maka dapat dilihat bahwa keluarga sangat berpengaruh dan memiliki tanggung jawab yang besar terhadap perkembangan anak, sehingga dapat berfungsi secara baik dalam ligkungan sosial dan anak mampu berkembang sesuai dengan tahapan perkembangannya (Ulfa \& Na'imah, 2020).

Fenomena yang terjadi terkait dengan adaptasi perubahan sistem pembelajaran daring ini memberikan dampak terhadap proses akademik peserta didik. Menurut (Syah, 2020) selama masa pandemi ini beban peserta didik menjadi lebih besar disebabkan dengan adanya upaya adaptasi untuk dapat menyesuaikan kondisi saat ini. Fenomena ini didukung oleh hasil penelitian yang dilakukan dibeberapa SMA di kota Banda Aceh yang membuktikan bahwa peserta didik mengalami kendala dalam menyelesaikan semua tugas-tugas yang diberikan guru selama pembelajaran daring berlangsung, hal ini diketahui disebabkan oleh adanya peserta didik yang mengalami ketidak selarasan antara dirinya dan kondisi lingkungan. Maka dari itu dengan berbagai perubahan yang dihadapi peserta didik tahun pertama selama pembelajaran daring ini akan sangat menuntut mereka dalam proses penyesuaian akademik untuk dapat mempengaruhi capaian dan prestasi mereka selama masa studi.

Berdasarkan teori Baker \& Siryk (1984) academic adjustment merujuk terhadap suatu proses perubahan psikologis yang membutuhkan usaha keras terhadap keseimbangan antara tugas akademik dan tujuan mereka, beserta adanya evaluasi positif dari upaya dan kualitas lingkungan akademik. Sedangkan academic adjustment atau penyesuaian akademik menurut Baker \& Siryk (1984) dapat dicerminkan melalui banyak segi, selain menjelaskan tentang kapasitas belajar siswa, penyesuaian akademik juga menjelaskan gambaran motivasi siswa terkait bagaimana siswa mengkonseptualisasikan tujuan akademik mereka melalui strategi yang mereka terapkan untuk mencapai tujuan tersebut, selain itu juga dapat menjelaskan tentang kepuasan siswa dengan lingkungan akademiknya. Baker \& Siryk (1984) menjelaskan bahwa academic adjustment meliputi motivasi individu dalam menyelesaikan tugas akademik, pencapaian dalam memenuhi syarat akademik, usaha yang berkaitan dengan akademis, dan kepuasan terhadap lingkungan akademiknya (Ardani, 2014). Lebih lanjut dijelaskan Baker \& Siryk 
(1999 dalam Waller, 2009) mengenai indikator yang termuat dalam academic adjustment, yakni motivasi, aplikasi, prestasi, dan lingkungan.

Schneider (1964 dalam Novadelian \& Rozali, 2020) menyebutkan bahwa terdapat enam aspek dalam penyesuaian akademik yang baik, yaitu Seccesful Performance, Adequate Effort, Acquisition of Worth While Knowledge, Intellectual Development, Achhievement of Academic Goals, Satisfaction of Needs, Desires, and Interests. Kemudian menambahkan bahwa academic adjustment merupakan kemampuan seseorang dalam menghadapi tuntutan dan ketentuan akademiknya, agar dapat terpenuhi dengan baik, tuntas dan memuaskan. Dalam hal ini dapat diperjelas bahwa peserta didik yang dapat dikatakan memenuhi tuntutan dan kewajiban akademiknya adalah mereka yang mampu menghadapi dan menganggap hambatan yang ada merupakan tantangan untuk memicu kemampuan dalam menyelesaikan tuntutan akademik yang diberikan, peserta didik tidak memandang hambatan sebagai halangan melainkan sebuah bentuk yang patut untuk diperjuangan sehingga peserta didik merasa memiliki tanggung jawab terhadap tuntutan yang ada dan memandang kesalahan adalah sebuah pembelajaran.

Baker \& Siryk (1984) menyebutkan empat indikator academic adjustment atau penyesuaian akademik, yaitu motivation yang berkaitan dengan motivasi peserta didik dalam mencapai tujuan akademik dan keberadaannya di universitas, application sebagai bentuk inisiatif yang diambil peserta didik demi mencapai tujuan akademiknya, performance merupakan bentuk efektifitas dari capaian akademis peserta didik, dan academic environtmen adalah wilayah universitas yang merupakan tempat peserta didik dalam melaksanakan proses dan kegiatan akademiknya. Dalam mencapai penyesuaian akademik yang baik, individu dapat dipengaruhi oleh adanya dukungan sosial, fisik dan emosional yang baik. Pada dasarnya keluarga meruapakan satuan kelompok sosial yang terkecil dan dapat mempengaruhi interaksi sosial individu yang kemudian dikembangkan pada masyarakat. Sejalan dengan hal tersebut, Epstein dkk. (1983) menjelaskan fungsi keluarga yaitu untuk mengembangkan setiap anggota keluarga dalam hal sosial, psikologis, dan fisik. Oleh karena itu, mahasiswa baru yang mengalami tekanan dan hambatan dalam penyesuaiannya membutuhkan dukungan tersebut. Keluarga yang dapat menjalani fungsinya merupakan keluarga yang fungsional atau dapat disebut sebagai keberfungsian keluarga.

McMaster Model of Family Functioning (MMFF) menggambarkan sifat struktural dan organisasi dari kelompok keluarga dan pola transaksi diantara anggota keluarga yang telah ditemukan untuk membedakan antara keluarga yang sehat dan tidak sehat. Model MMFF dikembangkan oleh Epstein dkk. (1983) selama lebih dari 40 tahun. MMFF ini mendeskripsikan perangkat struktur dan organisasi dari kelompok keluarga dan pola interaksi antara anggota keluarga yang dapat membedakan fungsi keluarga yang dapat membedakan antara fungsi keluarga yang dapat membedakan antara fungsi keluarga yang baik dan kurang baik. Terdapat enam dimensi dalam model MMFF, yaitu pemecahan masalah, komunikasi, peran, respon afektif, keterlibatan afektif, dan kontrol perilaku dan terdapat dimensi tambahan yaitu keberfungsian umum (Epstein dkk., 1983).

Penelitian ini bertujuan untuk menganalisis pengaruh keberfungsian keluarga terhadap academic adjustment pada mahasiswa tahun pertama selama proses pembelajaran dalam jaringan. Berdasarkan penjabaran tersebut dibuatlah hipotesis penelitian yang dijabarkan dengan hipotesis null $\left(\mathrm{H}_{0}\right)$, yaitu tidak terdapat pengaruh keberfungsian keluarga terhadap academic adjustment pada mahasiswa tahun pertama selama masa pembelajaran dalam jaringan dan hipotesis alternative $\left(\mathrm{H}_{\mathrm{a}}\right)$, yaitu terdapat pengaruh keberfungsian keluarga terhadap academic adjustment pada mahasiswa tahun pertama selama masa pembelajaran dalam jaringan. 


\section{E T O D E}

\section{Desain Penelitian}

Penelitian ini menggunakan pendekatan kuantitatif dengan metode survei melalui teknik pengumpulan data menggunakan kuesioner yang disebarkan secara daring melalui google form. Kuesioner penelitian ini berisi dua alat ukur penelitian dengan lampiran yang diawali data demografis berupa nama, jenis kelamin, usia, asal universitas, jurusan, dan tempat tinggal partisipan selama kuliah serta adanya lembar pernyataan kesediaan untuk menjadi partisipan dalam penelitian.

\section{Partisipan}

Populasi dalam penelitian ini dibatasi oleh kriteria yang telah ditetapkan, yaitu mahasiswa/i tahun pertama dalam hal ini adalah angktan 2020/2021 dan sedang melaksanakan pembelajaran dengan sistem daring serta tumbuh dan besar pada lingkungan keluarga sejak baru lahir. Teknik sampling yang digunakan pada penelitian ini adalah teknik snowball sampling yang merupakan sebuah teknik pengambilan sampel pada mulanya dengan melakukan sebaran pada jumlah kecil yang kemudian akan menyebar dan semakin banyak dengan cara meminta bantuan kepada partisipan untuk mengajar rekannya agar juga dijadikan sampel dan terjadi begitu seterusnya. Teknik ini diibaratkan seperti bola salju yang menggelinding. Jumlah partisipan pada penelitian ini adalah 254 dengan jumlah laki-laki sebanyak 44 dan perempuan 210 yang tersebar dari berbagai usia mulai dari 18 sampai dengan 25 dengan jumlah tertinggi pada usia 19 tahun sebanyak 125 partisipan dan dari berbagai universitas dengan jumlah tertinggi pada Universitas Negeri Gorontalo sebanyak 56 partisipan serta jurusan yang beragam dengan jumlah tertinggi pada jurusan psikologi dengan jumlah 32 partisipan. Di dalam kuesioner penelitian partisipan diminta untuk mengisi data partisipan guna melihat sebaran demografis dan mencermati petunjuk pengisian kuesioner yang berisi kesediaannya untuk menjadi partisipan penelitian.

\section{Pengukuran}

Guna mengetahui pengaruh keberfungsian keluarga terhadap academic adjustment pada mahasiswa tahun pertama selama proses pembelajaran daring maka peneliti menyusun kuesioner penelitian dengan tiga bagian yaitu bagian data demografis, skala variabel $\mathrm{X}$ dan skala variabel $\mathrm{Y}$. Instrumen penelitian yang digunakan dalam penelitian ini adalah model skala likert, yaitu skala Family Assessment Device oleh Epstein dkk., (1983) dengan jumlah 53 aitem yang bertujuan untuk mengukur keberfungsian keluarga, dengan koefisien reliabilitas $(\alpha=0,916)$. Sementara untuk mengukur academic adjustment digunakan skala Student Adaptation to College Questionnaire oleh Baker \& Siryk (1984) yang telah dimodifikasi sesuai konteks penelitian sehingga menjadi 20 aitem dengan koefisien reliabilitas $(\alpha=0,846)$.

\section{Analisis Data}

Teknik analisis data yang digunakan adalah regresi liner sederhana dengan bantuan software IBM SPSS Statistic 25 for Windows. Uji regresi linier sederhana digunakan sebab variabel dependen pada penelitian ini hanya dipengaruhi oleh satu variabel independen. Tahapan dalam melakukan uji regresi linier sederhana adalah dengan melakukan uji asumsi terlebih dahulu yang meliputi uji normalitas, uji linieritas dan uji heteroskedastisitas. 


\section{HAS I L P E N EL I T I A N}

\section{Analisis Deskriptif}

Hasil uji analisis statistik deskriptif dengan jumlah partisipan sebanyak ( $N=254)$, menunjukkan bahwa variabel keberfungsian keluarga memiliki nilai $(M=150,73 ; S D=16,641 ; M i n=95 ; M a x=191)$. Pada variabel academic adjustment memiliki nilai $(M=57,91 ; S D=7,099 ; \operatorname{Min}=39 ; \operatorname{Max}=80)$.

\section{Uji Hipotesis}

Tahapan dalam pengujian hipotesis yaitu dengan melakukan uji asumsi terlebih dahulu. Pada penelitian ini dilakukan uji normalitas residual dengan Kolmogorov-Smirnov yang menghasilkan nilai signifikansi sebesar 0,200 yang berarti data yang dihasilkan berdistribusi normal. Pada uji linieritas diperoleh nilai signifikansi sebesar 0,000<0,05 yang berarti data bersifat linier. Kemudian dilakukan uji heteroskedastisitas yang menghasilkan nilai residual variabel independen dengan nilai signifikan yang diperoleh adalah 0,694>0,05 yang berarti tidak terjadi gejala heteroskedastisitas.

\section{Uji Regresi Sederhana}

Uji regresi sederhana menghasilkan $\left(F(1,264)=79,979 ; p<0,01 ; R^{2}=0,297\right)$. Nilai ini menunjukkan tingkat keberfungsian keluarga dapat menjelaskan penyesuaian akademik sebesar 29,7\%. Variabel keberfungsian keluarga menghasilkan $(B=0,232 ; 95 \%$; $S E=0,023 ; t=6,698 ; p<0,01)$ yang menunjukkan nilai positif, sehingga jika tingkat keberfungsian keluarga yang dimiliki mahasiswa tahun pertama naik maka akan mempengaruhi tingkat penyesuaian akademik, begitupun sebaliknya jika keberfungsian keluarga yang dimiliki mahasiswa tahun pertama rendah maka akan mempengaruhi pada penurunan penyesuaian akademiknya.

\section{I S K U S I}

Berdasarkan data demografis subjek, diketahui bahwa responden tertinggi didominasi oleh mahasiswa tahun pertama pada usia 19 tahun dengan persentase 49,2\% atau sebanyak 125 responden yang berarti mayoritas subjek pada penelitian ini tergolong dalam usia remaja akhir. Menurut Erikson (1968 dalam Santrock, 2010) fase remaja akhir menjadi sebuah harapan setiap individu untuk dapat menangangi krisis identitas dan mencapai status identitas yang koheren. Pada fase ini mahasiswa akan dihadapkan dengan berbagai hal yang akan membentuk identitasnya yang ditandai oleh kemampuan dan komitmennya dalam berbagai peran kehidupan, utamanya dalam bidang karir, ideologi dan religius. Dalam mencapai tahap ini salah satu cara remaja, yaitu mahasiswa adalah dengan memahami identitasnya dalam persoalan karir melalui proses akademiknya. Sebelumnya terdapat penelitian yang dilakukan pada calon mahasiswa dalam masa tes masuk wawancara mahasiswa tahun pertama FIP Universitas Negeri Surabaya terkait dengan status identitas remaja akhir yang berhubungan dengan gaya pengasuh orang tua, dapat disimpulkan bahwa terdapat hubungan yang signifikan antara status identitas dan gaya pengasuhan orang tua dengan nilai koefisien korelasi kontigensi sebesari 0,701 yang berarti hubungan tersebut dapat dikatakan cukup kuat (Anindyajati, 2013). Hasil tersebut dijelaskan dalam pandangan Erikson (1968 dalam Santrock, 2010) bahwa resolusi identitas atau proses pencarian dan pembentukan identitas bersifat sosial dan salah satu variabel dalam lingkungan sosial yang erat kaitannya dengan remaja adalah keluarga. Sehingga keluarga dapat memberikan pengaruh besar pada perkembangan anak. Salah satu dimensi dalam keberfungsian keluarga yaitu peran, dimana perilaku yang dilakukan oleh anggota keluarga memiliki pola yang berulang dengan tujuan untuk memenuhi fungsi keluarga.

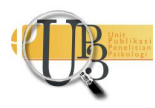


Hasil analisis uji regresi linier sederhana pada penelitian ini menunjukkan nilai signifikan sebesar 0,000 yang berarti terdapat pengaruh yang signifikan pada variabel keberfungsian keluarga terhadap variabel academic adjustment dengan koefisien regresi pada variabel keberfungsian keluarga yang bernilai positif yaitu sebesar 0,232 berarti setiap kenaikan 1 nilai keberfungsian keluarga maka akan menaikkan pula nilai academic adjustment sebesar 0,232. Hal serupa telah ditemukan pada penelitian sebelumnya yang dilakukan untuk melihat pengaruh orang tua terhadap academic adjustment. Ardani (2014) menemukan adanya hubungan antara kepedulian orang tua dan komunikasi yang baik dalam keluarga terdapat academic adjustment. Menurut Epstein dkk., (1983) pada keluarga yang sehat dan menjalankan fungsinya, komunikasi terjadi secara instrumental dan afektif yang merupakan cara dalam meningkatkan kemampuan coping terhadap krisis seperti problematika transisi pada mahasiswa tahun pertama.

Dalam mengukur aspek ini peneliti menggunakan skala Student Adjustment to College Questionnaire yang kemudian menunjukkan hasil presentase skala dari 254 responden terdapat $66 \%$ berada pada kategori sedang yang berarti sebagian besar mahasiswa tahun pertama memiliki penyesuaian akademik yang cukup dengan terpenuhinya beberapa indikator dalam academic adjustment menurut Baker \& Siryk (1984), yakni meliputi motivasi, aplikasi, performa dan lingkungan akademik. Penyesuaian akademik dapat menjelaskan gambaran motivasi peserta didik terkait dengan bagaimana peserta didik dapat mengoptimalisasikan tujuan akademik mereka melalui strategi yang mereka tetapkan untuk mencapai tujuan tersebut. Temuan pada penelitian ini sejalan dengan beberapa penelitian sebelumnya yang juga mengukur pengaruh berbagai faktor terhadap academic adjustment. Beberapa penelitian sebelumnya menunjukkan bahwa adanya penyesuaian akademik yang buruk pada peserta didik diantaranya disebabkan oleh motivasi akademik yang rendah, performa akademik yang buruk, serta adanya ketidak puasan terhadap lingkungan di sekolah. Adanya motivasi yang menurut pada peserta didik berdampak pada berbagai macam capaian akademik peserta didik dilingkungan akademiknya.

\section{S I M P U L A N}

Berdasarkan hasil analisis statistik yang telah dilakukan, maka dapat disimpulkan bahwa keberfungsian keluarga memiliki pengaruh yang signifikan terhadap academic adjustment pada mahasiswa tahun pertama dalam proses pembelajaran dalam jaringan.

Saran untuk penelitian selanjutnya, diharapkan untuk dapat mengukur keberfungsian keluarga dengan melibatkan anggota keluarga lainnya dalam partisipan penelitian sehingga akan lebih baik untuk melihat persepsi dari berbagai pihak. Selain itu, peneliti selanjutnya diharapkan dapat meneliti faktor lain yang ikut mempengaruhi academic adjustment seperti dari perspektif peer atau lingkungan akademik yang turut berkenaan langsung dengan mahasiswa

Saran untuk mahasiswa tahun pertama, diharapkan dapat memahami keberfungsian keluarga melalui komunikasi sehingga dapat menciptakan hubungan yang baik untuk memberikan dukungan terhadap setiap anggota keluarga khsuusnya seorang mahasiswa. Selain itu, mahasiswa tahun pertama perlu untuk memiliki rencana dan strategi dalam mencapai tujuan akademik melalui pemahaman terkait orientasi dan regulasi akademik yang disesuikan dengan kesiapan diri. 


\section{U C A P A N T ER I MAKASIH}

Peneliti mengucapkan terima kasih kepada seluruh pihak partisipan yang telah bersedia dalam memberikan kesediaannya pada penelitian ini serta berbagai pihak penelitian terdahulu yang telah membantu dalam memberikan rancangan penelitian melalui alat ukur.

\section{DEKLARASI POTENSI TERJADINYA KONFLIK KEPENTINGAN}

Silvia Febriyanti Igirisa dan Nono Hery Yoenanto tidak bekerja, menjadi konsultan, memiliki saham, atau menerima dana dari perusahaan atau organisasi manapun yang mungkin akan mengambil keuntungan dari diterbitkannya naskah ini.

\section{P US T AKA ACUAN}

Aji, R. H. S. (2020). Dampak Covid-19 pada Pendidikan di Indonesia: Sekolah, Keterampilan, dan Proses Pembelajaran. SALAM: Jurnal Sosial Dan Budaya Syar-I, 7(5). https://doi.org/10.15408/sjsbs.v7i5.15314

Anindyajati, P. D. (2013). Status Identitas Remaja Akhir: Hubungannya Dengan Gaya Pengasuhan Orangtua Dan Tingkat Kenakalan Remaja. Character: Jurnal Penelitian Psikologi, 1(2), 1-6.

Ardani, M. A. D., (2014). Hubungan antara family functioning dan academic adjustment pada mahasiswa baru Universitas Indonesia. [Skripsi, Universitas Indonesia]. http://lib.ui.ac.id/detail?id=20402471\&lokasi=lokal

Baker, R. W., \& Siryk, B. (1984). Measuring adjustment to college. Journal of Counseling Psychology, 31(2), 179-189. https://doi.org/10.1037//0022-0167.31.2.179

Epstein, N. B., Baldwin, L. M., \& Bishop, D. S. (1983). The Mcmaster Family Assessment Device. Journal of Marital and Family Therapy, 9(2), 171-180.

Fajriani, Yulizar, Bahri, S., \& Bakar, A. (2020). Penyesuaian Diri Siswa Terhadap Pembelajaran Daring di SMA Laboratorium Unsyiah pada Masa Pandemi Covid-19. Prosiding Seminar Nasional, 271-278.

Framanta, G. M. (2020). Pengaruh Lingkungan Keluarga Terhadap Kepribadian Anak. Jurnal Pendidikan Dan Konseling (JPDK), 2(1), 126-129. https://doi.org/10.31004/jpdk.v1i2.654

Hasanah, U., Ludiana, Immawati, \& PH, L. (2020). Gambaran Psikologis Mahasiswa Dalam Proses Pembelajaran Selama Pandemi Covid-19. Jurnal Keperawatan Jiwa, 8(3), 299-306.

Hikam, F. F. (2020). Peran Keluarga Dalam Pembelajaran Berbasis E-Learning Pada Masa Wabah Covid19. Jurnal Pendidikan Dan Dakwah, 2(2), 194-203.

Khotimatussannah, N., Khairunisya, N., Pitaliki, T., \& Anggraeni, A. (2021). Pengaruh Efikasi Diri terhadap Penyesuaian Akademik di Masa Pembelajaran. Jurnal Sosial Dan Humaniora, 3(1), 29-36. http://ejournal.umbandung.ac.id/index.php/rasi/article/view/120

Novadelian, A., \& Rozali, Y. A. (2020). Perbedaan Penyesuaian Akademik Ditinjau dari Kategorisasi Adversity Intelligence pada Santri MTS Pondok Pesantren Daar el-Qolam 1 Jayanti, Tangerang. UEU Jurnal. 
Santrock, J. W. (2010). Life-Span Development. Boston: McGraw-Hill Higher Education.

Saragih, M., Silitonga, E., Sinaga, T. R., \& Mislika, M. (2021). Hubungan Dukungan Keluarga Dengan Motivasi Belajar Mahasiswa Selama Pandemi Covid-19. Jurnal Ilmiah Keperawatan Imelda, 7(1), 73-77. https://jurnal.uimedan.ac.id/index.php/JURNALKEPERAWATAN/article/view/494/504

Sulfiana, E. (2015). HUBUNGAN ANTARA SELF EFFICACY ACADEMIC DENGAN PENYESUAIAN AKADEMIK PADA MAHASISWA UIN SUNAN AMPEL SURABAYA [Skripsi, Universitas Islam Negeri Sunan Ampel Surabaya].

Ulfa, M., \& Na'imah. (2020). Peran Keluarga dalam Konsep Psikologi Perkembangan Anak Usia Dini. Aulad : Journal on Early Childhood, 3(1), 20-28. https://doi.org/10.31004/aulad.v3i1.45

Waller, T. (2009). A mixed method approach for assessing the adjustment of incoming first-year engineering students in a summer bridge program (Doctoral dissertation, Virginia Tech). 